\title{
A HISTORICAL EXPOSITION OF SPATIAL INJUSTICE AND SEGREGATED URBAN SETTLEMENT IN SOUTH AFRICA
}

\author{
Margot Strauss
}

\begin{abstract}
Spatial injustice and urban residential segregation represent significant dimensions in the historical development of the settlement patterns of South Africa's urban poor, which have strong links to colonialism and apartheid. A myriad of political, economic, legal and social factors contributed to the legacy of spatial injustice and socioeconomic exclusion that characterises contemporary towns and cities. This contribution provides a historical exposition of the leading causes of spatial injustice and segregated urban settlement in South Africa during colonialism and apartheid, and adopts a spatial perspective in its analysis of relevant legislation, case law and academic literature. Advancing this critical spatial awareness is essential, as it remains elusive in current approaches to the interpretation and implementation of the housing rights of South Africa's urban poor.
\end{abstract}

Keywords: Spatial injustice; segregated urban settlement; South Africa; legislation; housing; planning; land

* Researcher, Department of Public Law, Faculty of Law, Stellenbosch University. This contribution is based on ch 2 of my unpublished LLD thesis entitled A Right to the City for South Africa's Urban Poor (Stellenbosch University, 2017). 


\section{Introduction}

A myriad of political, economic, legal and social factors contributed to the legacy of spatial injustice and exclusion that characterises South Africa's contemporary urban areas and segregated settlement patterns. ${ }^{1}$ This contribution provides a historical exposition of the leading causes of spatial injustice and segregated urban settlement in South Africa during colonialism and apartheid. Furthermore, it adopts a spatial perspective in its analysis of relevant legislation, case law and academic literature. Advancing this critical spatial awareness is essential, as it remains elusive in current approaches to the interpretation and implementation of the housing rights of South Africa's urban poor. ${ }^{2}$

The historical analysis consists of three main parts that correspond to distinct periods between 1652 and $1990 .{ }^{3}$ Part one examines the colonial roots of spatial control and residential segregation in South Africa's earliest towns (1652-1910). Part two reviews the post-Union or pre-apartheid period (1910-1948) and investigates the use of law as an instrument to legitimate and advance the systematic dispossession, spatial segregation, political control and socio-economic exclusion of the majority black population. The final part of this contribution explores the apartheid state's use of legislation between 1948 and 1990 to consolidate spatial control, entrench segregated housing settlement and facilitate the spatial restructuring of urban areas.

\section{Pre-colonial African settlement patterns}

Prior to the colonial occupation of southern Africa, sizeable settlements developed as strategically located agrarian and economic nodes along prominent trading routes. ${ }^{4}$ Stone-walled structures often demarcated the spatial organisation and main settlement features, which included administrative courts and the homesteads of prominent figures. ${ }^{5}$ Settlement patterns also evinced political hierarchies and advanced social

$1 \quad$ Pienaar 2002b: 337; National Planning Commission 2012: 259-276.

2 Strauss \& Liebenberg 2014: 428; Strauss 2017: 181-243.

3 In South Africa, colonialism officially commenced in 1652, when the Dutch founded a permanent settlement at the Cape. On 31 May 1910, the amalgamation of four British colonies (the Cape of Good Hope, Natal, Transvaal and Orange River) established the Union of South Africa in terms of the Union of South Africa Act of 1909. This date marks the end of the colonial period and the beginning of the post-Union or pre-apartheid period. See, further, Terreblanche 2002: 199; Van Wyk 2012: 25 .

4 The location of these early settlements facilitated access to agricultural and mineral resources, which stimulated regional trade and increased the political influence and economic power of their inhabitants. The Zimbabwean capital of Mapungubwe (1075-1220), for instance, developed along a trading route through the Limpopo River valley that extends from Botswana to the Indian Ocean. Mapungubwe provided the foundation for the establishment of the pre-colonial Kingdom of Zimbabwe (1220-1450). See Huffman 1992: 676-680; Harrison, Todes \& Watson 2008: 19.

5 In addition to built structures, rights of way distinctly separated the living environments in these pre-colonial indigenous settlements; their particular spatial layout is evident in, for example, the villages of the Tswana chiefdoms and the capitals of the Zulu Kingdom. See Mabin 1992b: 13; Van Wyk 2012: 26. 
structures: while most residents lived within the enclosure, prominent families occasionally resided outside built-up areas. ${ }^{6}$ At the height of their development, complex political, economic, legal and social relations characterised the organised and functional living environments of strategically located African settlements. ${ }^{7}$

From the mid-seventeenth century, a series of significant events severely disrupted the settlement patterns and livelihood strategies of southern African communities. Most notably, prolonged periods of ethnic warfare, major droughts and famine resulted in large-scale forced migration. ${ }^{8}$ The advent of colonialism and the development of early European settlements contributed to conditions that exacerbated the spatial displacement of African populations due to an increased scarcity of arable land and livestock, demands for slave labour, and trade in valuable resources. ${ }^{9}$

Spatial segregation represents a significant dimension in the historical development of urban settlement patterns in South Africa and is deeply rooted in the colonial period. ${ }^{10}$ The next section examines the origins and impact of the formal establishment and administrative control of spatially segregated residential settlements in South Africa's earliest major colonial towns. ${ }^{11}$

\section{Colonial origins of spatially segregated urban settlement (1652-1910)}

\section{Administering spatial control through separate residential "locations"}

Upon arriving in the Cape in 1652, the Dutch introduced their system of land registration and planning in the earliest colonial settlements established predominantly for administrative and agricultural purposes. ${ }^{12}$ These initial approaches to land-use management were informed by the notion that the land inhabited by indigenous communities was res nullius. ${ }^{13}$ After the British invasion and conquest of the Cape in 1795, they maintained the Roman-Dutch legal system, but introduced their own

6 These political and social hierarchies and structures are evident in both the regional distribution of residential complexes and the layout of administrative capitals. See Huffman 1992: 678-679.

7 Laburn-Peart 2002: 269.

8 Eldredge 1992: 29-31; Harrison, Todes \& Watson 2008: 19-20.

9 Van Wyk 2012: 28; Pienaar 2014: 54-55.

10 Maylam 1995: 22.

11 For an account of the origins and impact of urban residential segregation in the Boer republics of the Transvaal and Orange Free State during the late nineteenth century, see Parnell 1991: 273; Maylam 1995: 23.

12 Van Wyk 2012: 27.

13 Badenhorst, Pienaar \& Mostert 2006: 32; Van Wyk 2012: 27. 
administrative practices. ${ }^{14}$ Authorities did not recognise any immediate need for formal planning or restrictive measures, as land-use segregation trends in early colonial towns reflected low property values and the slow nature of development. ${ }^{15}$

Founded as a British colonial port, the town of Port Elizabeth represents one of the primary sites in South Africa where spatially segregated urban development occurred along racial lines. ${ }^{16}$ As the initial spatial design of the colonial outpost catered exclusively for European needs ${ }^{17}$ missionaries founded a so-called location or separate residential area near the town centre for indigenous persons under their care in $1834 .{ }^{18} \mathrm{An}$ influx of black labourers seeking access to livelihood opportunities over the next two decades prompted the municipality in 1855 to establish the Native Strangers' Location adjacent to the 1834 location. ${ }^{19}$

The development of the Native Strangers' Location is historically significant, as it provides insight into early colonial approaches that used segregated residential development as a mechanism of urban administration and spatial control. ${ }^{20}$ Due to the participation of colonial officers, the spatial relocation of black residents to the Native Strangers' Location also represents one of the first authorised forced removals in a South African urban area. ${ }^{21}$ Black labourers who, for instance, were not housed

14 In Alexkor Ltd v Richtersveld Community 2004 (5) SA 460 (CC) pars 32, 45, 62 and 68-77, the South African Constitutional Court considered the nature and content of an indigenous community's land rights before and after the British acquisition of the land in 1847 . The case dealt with a claim for restitution of land by the Richtersveld community under the provisions of the Restitution of Land Rights Act 22 of 1994. Central to the claim was the question whether the Richtersveld community was dispossessed of its land rights after 19 Jun 1913 as a result of discriminatory laws or practices. The court found that the real nature of the community's title was a right of communal ownership under indigenous law, which included the right to the exclusive occupation and use of the land. The court concluded that there was nothing in the events preceding the annexation of the Richtersveld that suggested that annexation extinguished the community's land rights.

15 Van Wyk 2012: 28.

16 By the mid-nineteenth century, Port Elizabeth was the town with the second-largest population in South Africa after Cape Town. See Kirk 1991: 295. The colonial settlement of East London represents another prominent site where racially segregated development occurred in as early as 1849. However, military considerations largely determined its spatial organisation. See Nel 1991: $60-68$.

17 Mabin 1991: 9.

18 The London Missionary Society Outstation or location was located less than a kilometre from the Port Elizabeth town centre, but was separated from it by cemeteries and open land. See Christopher 1987: 197; Baines 1990: 72.

19 The Native Strangers' Location was intended exclusively for black labourers, who were considered as temporary residents. The landholding system in the settlement was based on an extended leasehold period, which could be renewed annually. Although the land was not individually owned, some tenants lived on their plots long enough to attain common-law rights or tenure through occupancy. See Kirk 1991: 304.

20 Joyce Kirk argues that, contrary to studies indicating that urban residential segregation originated during the $1880 \mathrm{~s}$ - when the closed compound housing system developed in Kimberley - it commenced with the establishment of the Native Strangers' Location. See idem at 294.

21 Ibid. 
by their employers were required to relocate to this regulated area and to construct their own housing. ${ }^{22}$ Despite the proximity of the Native Strangers' Location to urban amenities and opportunities, its occupants faced significant challenges. Local authorities prohibited tenants from improving or adapting their homes, which rendered structures unsafe and contributed to poor living conditions. Harsh restrictions also affected fragile livelihood strategies, as inhabitants were prevented from supplementing their income by renting out rooms or allowing others to erect structures on their plots. As a result, they frequently built structures or accommodated boarders without obtaining permission from local authorities. The establishment of the Native Strangers' Location thus provides valuable insight into the resolve and efforts of marginalised black urban inhabitants to overcome the political, social and spatial challenges associated with their living environments in order to meet their particular needs - despite the formal restrictions and criminal sanctions imposed by colonial authorities. ${ }^{23}$

Although Port Elizabeth's black labour force initially resided in different types of well-located accommodation, ${ }^{24}$ local authorities eventually established additional residential locations beyond the urban boundary as the town expanded..$^{25}$ This decision was ostensibly aimed at alleviating overcrowding and poor living conditions in the Native Strangers' Location. ${ }^{26}$ In practice, however, it ensured greater colonial control over new residential areas reserved for black urban inhabitants.

Towards the end of the nineteenth century, the prime geographical placement of the Native Strangers' Location near Port Elizabeth's town centre began to impede the development of areas earmarked for Europeans. In response, the white population increasingly demanded the removal of the black settlement from its proximity to their new neighbourhoods. ${ }^{27}$ The value of the land occupied by the location also increased significantly and the site was earmarked for commercial and industrial

22 Black persons squatting on private land or on the town commonage were also forced to relocate to the Native Strangers' Location. See Christopher 1987: 197; Baines 1990: 74-75.

23 Kirk 1991: 305.

24 In addition to the residential locations, black inhabitants resided in rental accommodation and housing provided by employers. See idem at 295.

25 These locations included Dassiekraal (1850), Cooper's Kloof Location (1877) and the Reservoir Location (1883). All the locations were established on municipal land. The regulations applicable to these new locations differed, however, from those governing the Native Strangers' Location. In Cooper's Kloof, for instance, the municipality limited the leasehold period to three years and retained the right to remove tenants at any time within the terms of the lease agreement. This had a significant impact on residents' economic and social position, as they had the status of shortterm tenants and were subject to evictions. Notably, Port Elizabeth's local authorities did not administer the Gubbs Location, as it developed on privately owned land. This allowed its inhabitants greater freedom to maintain aspects of traditional life.

26 In addition to overcrowding and poor living conditions, there was limited access to essential services (such as water standpipes) in the Native Strangers' Location. See Kirk 1991: 304-306, 310.

27 Christopher 1991: 44. 
development. ${ }^{28}$ In 1883 , the Port Elizabeth municipality attempted to introduce legislation authorising the removal of the Native Strangers' Location and the relocation of its residents..$^{29}$ This approach was modelled on the use of legislation in the Cape Colony, where British officials enacted the Native Administration Act 3 of 1876 and the Native Locations, Lands and Commonages Act 40 of 1879 in order to exercise greater control over black persons residing on public and private land. In particular, the Native Reserve Locations Act 40 of 1902 granted British authorities the power to establish black residential areas on the outskirts of urban areas..$^{30}$

The residents of Port Elizabeth's Native Strangers' Location resisted their relocation, as it would exacerbate their marginalisation, affect their livelihood strategies and social networks, and deprive them of existing access to employment opportunities and facilities, such as schools and churches. Although the Native Strangers' Location Bill was ultimately unsuccessful, the municipality's attempt to introduce legislation aimed at evicting and relocating black inhabitants fuelled a broader and prolonged dispute between them and the town's authorities. ${ }^{31}$

In 1901, an outbreak of the bubonic plague provided the necessary impetus for health authorities to evict and relocate the occupants of the Native Strangers' Location to an outlying area. The decision to relocate these black urban inhabitants, instead of providing them with access to housing in town, was deliberate and aligned with the municipality's broader strategy of advancing urban residential segregation. Stated differently, colonial officials maintained control over the presence of black labourers in the town without addressing their unsafe housing and unhealthy living conditions. Many evictees relocated to Korsten, a mixed-race freehold village, where they purchased land. ${ }^{32}$ In the following year, the Port Elizabeth municipality implemented the Native Reserve Locations Act 40 of 1902 to establish New Brighton - the first official urban so-called township (or separate residential area for black inhabitants). ${ }^{33}$ In doing so, New Brighton became both a physical, spatial expression and legal precedent for the future development of racially segregated urban residential settlement in South Africa. ${ }^{34}$

28 Kirk 1991: 294, 312-313.

29 Local authorities in Port Elizabeth introduced the Native Strangers' Location Bill in 1883. See idem at 295, 300, 314.

30 In terms of the Native Reserve Locations Act 40 of 1902, black residents from District Six and other parts of Cape Town were forcibly relocated to the outlying area of Ndabeni.

31 The members of an emerging black middle class were particularly opposed to the strategy of forced removal and its impact on their status, specifically in relation to their prescriptive land rights in the location. See Kirk 1991: 314-317.

32 Idem at 306, 319-320.

33 During this period, two similar statutes were passed in Natal. The Native Locations Act 37 of 1897 enabled the heightened administration of locations, while the Native Reserve Locations Act 2 of 1904 enabled local authorities to establish locations. See Van Wyk 2012: 48.

34 Kirk 1991: 320. See, further, Mabin \& Smith 1997: 199. 
Advancing political, economic, social and spatial control through the physical demarcation and administration of separate black locations represent prominent features of the colonial period. The role of the law in facilitating spatially unjust settlement patterns, urban residential segregation, the privileging of white minority property and economic interests, as well as legitimising the forced removal of black urban inhabitants to remote sites beyond the urban boundary, is equally conspicuous. Despite considerable challenges, the analysis of the Native Strangers' Location in Port Elizabeth illustrates that locations also represented sites of political contestation, where black residents undermined and challenged colonial authorities' attempts at spatial control through their daily lives and collective activities.

As noted above, public health administration played a role in exercising spatial control and facilitating segregated urban development and housing deprivation during the colonial period. The use of the law to address the causal connection between the presence of black persons in urban areas and perceived threats to the white population's health and safety is considered in the next section.

\section{The role of public health legislation in the spatial organisation of colonial towns}

At the turn of the twentieth century, the spread of infectious diseases throughout colonial towns resulted in a powerful societal metaphor, which influenced the establishment of institutions and legal frameworks that heightened spatial segregation and racial tensions. Authorities' attempts to control infectious diseases reveal important insights into two sets of relationships in urban areas. The first encompassed the social interaction between inhabitants of different racial groups, while the second concerned urban residents' relations to their physical surroundings..$^{35}$ The "sanitation syndrome" ${ }^{36}$ explains spatial control and exclusionary urban development in terms of the "moral panic and racial hysteria" of white residents who increasingly equated the presence of black persons in urban areas with poverty, disease and crime ${ }^{37}$ As a result, a causal connection developed between perceived threats to the white population's health and safety, and the imperative to achieve racially motivated spatial quarantines through the forced removal of black communities from urban areas. ${ }^{38}$

In Cape Town, for instance, the eruption of the plague in 1901 resulted in the swift relocation of more than 6000 black persons from the urban centre to temporary

35 Swanson 1973: 160; Swanson 1977: 387.

36 Emphasising the metaphorical significance of the syndrome, Swanson 1977: 409 explains that urban race relations were "widely conceived and dealt with in the imagery of infection and epidemic disease". See, further, Swanson 1973: 160.

37 Maylam 1995: 24.

38 Ibid. 
accommodation in the outlying area of Ndabeni. ${ }^{39}$ Similarly, in Port Elizabeth, the onset of the plague prompted the municipality to demolish the Native Strangers' Location and to establish the segregated township of New Brighton. ${ }^{40}$ Local authorities in Johannesburg also used the outbreak of the plague to justify the removal of so-called Indian inhabitants from the inner city "Coolie Location" to the peripheral township of Klipspruit. ${ }^{41}$ Ultimately, the use of public health legislation to establish and manage separate, peripheral housing spaces for black inhabitants formed part of a broader strategy aimed at promoting spatially unjust urban development and the political, economic and social exclusion of certain communities and individuals.

The subsequent section examines the use of town planning and land-use management practices to justify and facilitate the forced removal, spatial displacement and dispossession of black communities.

\section{Facilitating spatial displacement through planning and land-use management}

Under colonial rule, formal planning methods were either superimposed on indigenous settlement patterns and land-use systems, or implemented alongside preexisting historic urban centres. ${ }^{42}$ Municipal officials also strictly regulated housing development in the separate residential locations, while implementing limited or unsuitable town planning practices. In contrast, neighbourhoods where white persons resided were increasingly characterised by low-density layouts, public spaces, green belts and access to superior infrastructure and municipal services. ${ }^{43}$ In practice, planning practices in areas reserved for black inhabitants accordingly differed significantly from those applied to white residential areas. Settlement plans applicable to black residential areas were not, for instance, sensitive towards the particularly complex domestic and economic responsibilities of women. The uncritical implementation of European planning norms also incorrectly assumed that black people would have nuclear families and that they preferred to keep their places of residence and employment separate. Moreover, local planning practices failed to accommodate the religious or culturally specific needs of black, Indian, and so-called coloured families and communities living in urban areas. Planning approaches in black residential areas were thus wholly incompatible with the particular employment patterns and with the domestic, social and cultural needs of their inhabitants. ${ }^{44}$ Stated differently, municipal planning approaches largely failed to adequately respond to the diverse housing needs of growing, heterogeneous urban populations, which further

39 Swanson 1977: 392; Maylam 1995: 24.

40 Swanson 1977: 400; Christopher 1987: 197.

41 Parnell 1991: 273; Maylam 1995: 24-25.

42 Hardoy \& Satterthwaite 1989: 20.

43 Rakodi 1986: 201.

44 Hardoy \& Satterthwaite 1989: 22-23. 
exacerbated the economic, social and spatial exclusion of already marginalised black inhabitants. As a result, housing deprivation, overcrowding and unsafe and unhealthy living conditions afflicted these areas. ${ }^{45}$

Introducing planning legislation to improve the living conditions of black urban residents proved ineffectual. This was largely due to the fact that these legal frameworks were based on Western models and designed for economies and societies that were entirely distinct from the actual contexts in which they were implemented. ${ }^{46}$ In particular, statutory planning frameworks failed to recognise non- European conceptions of divisions between public and private spaces, as well as the specific transportation needs of black persons. The extent of the impact of colonial planning practices on black settlement patterns remains evident in many of the social power imbalances and spatial inequalities inherent in contemporary South African urban areas. ${ }^{47}$

From the mid-nineteenth century, industrial and economic development, coupled with the mineral revolution, added a further dimension to spatial control and urban segregation in the colonies. ${ }^{48} \mathrm{An}$ influx of investment and the expansion of economic and mining activities resulted in rapid and unrestrained urbanisation, which had a profound impact on the spatial organisation of urban areas. ${ }^{49}$ Industrial, commercial and residential sites often developed adjacent to one another. The haphazard nature of urban development spurred the need for formal town planning in relation to residential areas, ports, transportation networks and commercial centres. ${ }^{50}$ Local planning authorities drew inspiration from British land-use management practices in their efforts to spatially reconfigure colonial towns. ${ }^{51}$ The spatial settlement patterns that developed during the 1880s in industrial or mining towns, such as Kimberley, represent an important source of urban residential segregation in South Africa. This is due to the fact that the housing compounds and hostels near mines that accommodated black labourers represented a rigid form of residential segregation, which structured the development of South African cities. ${ }^{52}$ In the British colony of Natal, for example, racially discriminatory housing policies only permitted black persons to access urban areas as single workers, housed in either municipal or private dormitories. ${ }^{53}$

The rise of industrialisation coincided with substantial population migration towards economic opportunities in towns. Aggressive labour recruiting practices

45 Rakodi 1986: 201

46 Hardoy \& Satterthwaite 1989: 21-22; Mabin 1992b: 15-17.

47 Gugler 1996: 221-225; Hardoy \& Satterthwaite 1989: 22-23.

48 Maylam 1995: 23

49 Rapid urbanisation in South Africa was due to a combination of natural increase and large-scale migration to urban areas. See Van Wyk 2012: 21.

50 Mabin 1992b: 14; Van Wyk 2012: 21.

51 Van Wyk 2012: 21.

52 Mabin 1986: 22. See, further, Pirie 1991: 120-128.

53 Christopher 1990: 425. 
for emerging industries attracted people of different races and classes. ${ }^{54}$ This process perpetuated existing class differentiation and entrenched racial and spatial inequalities in residential areas. Although both white and black labourers were susceptible to changing trends, their migratory patterns differed vastly. The combined pressure of land deprivation, forced displacement and deepening levels of poverty and inequality had a profound impact on black persons. As a result, struggling rural black communities increasingly attempted to access the small urban economy. The settlement patterns of black migrants in urban areas varied according to the period they spent in towns and the participation of their households in the migratory process. For example, entire families often did not migrate to urban areas in order to maintain a home in the rural reserves. ${ }^{55}$ Significantly, this trend illustrates that even though market conditions contributed to the control of the spatial settlement patterns of black labourers in urban areas, the white-minority dominated economy relied heavily on rural areas for a consistent supply of migrant labour. ${ }^{56}$

Land-use planning and management further entrenched the spatial control and dispossession of black communities,${ }^{57}$ as applicable legal frameworks provided that land could not be registered in the name of a "native", "Bantu" or "Black" ${ }^{58}$ The exclusionary nature of land ownership was justified on the basis of article 13 of the Pretoria Convention of $1881 .{ }^{59}$ Subsequent legislation also provided for a variety of restrictions on the use and occupation of land by black persons. ${ }^{60}$ The enactment of the Glen Grey Act of 1894, for instance, brought an end to black communal land

54 Harrison, Todes \& Watson 2008: 21

55 Mabin 1992b: 14-15.

56 Harrison, Todes \& Watson 2008: 22.

57 The Grondwetten van de Zuid-Afrikaansche Republiek (Constitutions of the South African Republic) of 1858, 1889 and 1896 all advanced the principle of non-equality, which provided that black persons could not have equal rights with white people. See, further, Van Wyk 2012: 30.

58 Colonial authorities used the terms "Native", "Bantu", and "Black" interchangeably. Accordingly, the names of statutes were subsequently amended to coincide with the official use of these terms. For example, the Natives Land Act 27 of 1913 was amended to the Bantu Land Act 27 of 1913 and later became known as the Black Land Act 27 of 1913. See Van Wyk 2012: 30. On the use of constructed race terms in law during the colonial and apartheid periods, see, further, Bunting 1964: 159-160 and 189. For an analysis of the use of race and racial categories as historical and unscientific social constructs, see Smedley \& Smedley 2005: 16. Any reference to race or racial categories made in this contribution is made with this in mind.

59 Article 13 of the Pretoria Convention of 1881 stated that "[n]atives will be allowed to acquire land, but the grant of transfer of such land will in every case be made to and registered in the name of the Native Location Commission ... in trust for such natives". See, also, Tongoane v Minister of Agricultural and Land Affairs 2010 (6) SA 214 (CC) par 10.

60 Article 9 of the 1858 Grondwet van de Zuid-Afrikaansche Republiek provided, for instance, that the "people will not permit any equalisation of 'Coloured' persons with white inhabitants, neither in Church nor State". See, further, Lewis 1985: 251; Van Wyk 2012: 30. 
rights in the Cape colony. ${ }^{61}$ In the Transvaal, the Precious and Base Metals Act 35 of 1908 also restricted the occupation of certain land by black families and individuals. ${ }^{62}$ In 1905, Tsewu $v$ Registrar of Deeds ${ }^{63}$ held that article 13 of the Pretoria Convention of 1881 did not have the status of law and that black persons could register land titles in their own names. ${ }^{64}$ Between 1905 and June 1913, black individuals purchased approximately 399 farms. ${ }^{65}$ However, the enactment of the Black Land Act 27 of 1913 fundamentally changed this situation, as it restricted the rights of black persons to own or occupy land outside the legally defined rural reserves or homelands. ${ }^{66}$

Spatial control and segregated urban development thus represent significant dimensions in the historical development of South African towns, which are deeply rooted in the colonial period. The next section analyses the use of legal frameworks to produce the foundations for the spatial control of urban settlement in the postUnion period between 1910 and 1948.

\section{$4 \quad$ Establishing the pre-apartheid foundations of spatial control and segregated urban development (1910- 1948)}

\section{Advancing spatial segregation through land dispossession}

The amalgamation of the four British colonies established the Union of South Africa in 1910. Between 1910 and 1948, the Union government developed legal mechanisms aimed at effecting spatial control in the areas of land-use management, town planning, housing and public administration. These measures gradually entrenched the segregation and socio-economic exclusion of the majority black population, while establishing the legal foundation for segregated urban development during apartheid.

61 The Glen Grey Act of 1894 (Cape) regulated African settlement patterns in the Cape colony through the introduction of labour taxes and the limitation of individual land holdings. The Act resulted in the forced displacement of thousands of black persons. It also sought to undermine the traditional chieftains system, as tribal authorities represented an independent political voice that resisted changes imposed by colonial authorities. See Davenport \& Saunders 2000: 129-193. See, further, Bouch 1993: 1-24.

62 Harrison, Todes \& Watson 2008: 20-21.

631905 TS 130.

64 In idem at 135, the court cited art 13 of the Pretoria Convention of 1881 and stated that "[1]eave shall be given to natives to obtain ground, but the passing of transfer of such ground shall in every case be made to and registered in the name of the Commission for Kafir Locations ... for the benefit of such natives". See, further, Tongoane v Minister of Agriculture and Land Affairs 2010 (6) SA 214 (CC) par 11; Loveland 1999: 76.

65 Feinberg 1995: 50; Davenport \& Saunders 2000: 129-156.

66 Tongoane v Minister of Agriculture and Land Affairs 2010 (6) SA 214 (CC) par 11. 
The Black Land Act 27 of 1913 laid the foundation for dispossession by demarcating the spaces within which black residents could legally settle. ${ }^{67} \mathrm{By}$ deliberately restricting areas where black persons could lawfully purchase, hire or occupy land to scheduled reserves in rural areas, ${ }^{68}$ the Act excluded them from accessing vast portions of land in South Africa. ${ }^{69}$ Additionally, it reduced the status of black labourers who remained in areas designated for the exclusive benefit of white employers to that of labour tenants or squatters..$^{70}$ These restrictions assisted in advancing the economic participation of white labourers who struggled to compete with skilled and semi-skilled black labourers. ${ }^{71}$ In urban areas, the Black Land Act 27 of 1913 further regulated spatial settlement patterns by limiting the livelihood opportunities of black labourers, who were only accommodated as members of a temporary workforce.

The Development Trust and Land Act 18 of 1936 extended the application of the Black Land Act 27 of 1913 by providing for the acquisition of additional scheduled areas or rural reserves designated for black inhabitants. ${ }^{72}$ The Development Trust and Land Act 18 of 1936 integrated land identified by the Black Land Act 27 of 1913 into these reserves and formalised the racial segregation of rural areas through the mechanism of the South African Native Trust. ${ }^{73}$ Although the land held by the Trust was intended for the "exclusive use and benefit" of black communities, the

67 Van Wyk 2012: 43.

68 Sections 1 and 2 of the Black Land Act 27 of 1913. In terms of s 10 of the Act, a "scheduled native area" was any area in a province or homeland listed in the Schedule to the Act. These scheduled areas were the forerunners for the establishment of the Bantustans or independent homelands during apartheid.

69 Section 1(1) of the Black Land Act 27 of 1913 prohibited the sale of land located outside the scheduled areas listed in the Act between a black person and a person "other than a native". Section 1(2) of the Act provided that, in exceptional circumstances, the Governor General could approve the sale of land to black persons in terms of the Black Administration Act 38 of 1927. This land was, however, not registered in the name of the purchaser. Instead, the Minister of Native Affairs held the land in trust and recognised the permanent use and occupation rights of the purchaser in respect of the land. See Tongoane v Minister of Agriculture and Land Affairs 2010 (6) SA 214 (CC) pars 12-13; Van Wyk 2012: 43.

70 Section 6 read with s 2 of the Black Land Act 27 of 1913. In order to remain on land outside of the scheduled reserves, while avoiding criminal prosecution in terms of s 5 of the Act, black persons concluded labour tenant contracts with white farmers. The Black Service Contract Act 24 of 1932 regulated labour tenancy in South Africa during the pre-apartheid period. See Van der Walt 2009: 135; Van Wyk 2012: 43.

71 Maylam 1995: 26. See, further, Parnell 1993: 473-476.

72 Tongoane v Minister of Agriculture and Land Affairs 2010 (6) SA 214 (CC) pars 12-15; Van Wyk 2012: 31

73 Sections 4 to 9 of the Development Trust and Land Act 18 of 1936. In terms of s 6 of the Act, all land that was set aside for the use and occupation of black persons vested in the South African Native Trust. Tribal authorities administrated the land held by the Trust in terms of s 4(3) of the Act. See Western Cape Provincial Government: In re DVB Behuising (Pty) Ltd v North West Provincial Government 2000 (4) BCLR 347 (CC) pars 76-77. 
amount of land that it could acquire was restricted. ${ }^{74}$ In particular, section 10(1) of the Development Trust and Land Act 18 of 1936 established control over spatial settlement patterns by limiting land allocated for black persons to 13 per cent of the country's total surface area. ${ }^{75}$ In doing so, it secured the remaining 87 per cent of the land for the white minority's unfettered use and occupation. At local level, the Act facilitated the spatial exclusion and socio-economic marginalisation of black persons by requiring them to settle in remote townships in the reserves. ${ }^{76}$

During the pre-apartheid period, the Black Land Act 27 of 1913 and the Development Trust and Land Act 18 of 1936 facilitated dispossession by restricting land allocated for black occupants to the rural reserves, which were important sources of migrant labour. In practice, this legislative framework thus placed extensive restrictions on the use, occupation and ownership rights of black inhabitants and limited their participation in urban society to meeting the functional needs of the white economy. ${ }^{77}$ These statutes also legitimated the government's control over the settlement patterns, and demarcated areas where black persons were forced to reside.

The government's use of legislative instruments to enhance spatial control and segregation at the intersection of planning and housing is analysed in the next section.

\section{Enhancing spatial control at the intersection of planning and housing}

The Black (Urban Areas) Act 21 of $1923^{78}$ enabled the development of separate residential areas for black residents in the vicinity of urban centres. In particular, the Act regulated the housing spaces where black inhabitants could legally settle by

74 Section 48(1)(g) of the Development Trust and Land Act 18 of 1936 authorised the South African Native Trust to "grant, sell, lease or otherwise dispose of land" to black persons on certain conditions. Additionally, the provision empowered the Governor General to issue regulations prescribing the conditions under which black persons could purchase, hire or occupy land held by the Trust. Section 48(1)(i) provided for the allocation of land held by the Trust for residential purposes. See Tongoane v Minister of Agriculture and Land Affairs 2010 (6) SA 214 (CC) par 14.

75 Western Cape Provincial Government: In re DVB Behuising (Pty) Ltd v North West Provincial Government 2000 (4) BCLR 347 (CC) par 2. See, further, Ross 2008: 95-96; Robertson 1990: $128-129$.

76 Van Wyk 2012: 31.

77 This legislative framework also established the foundation for subsequent legislation that entrenched the dispossession and spatial exclusion of black persons during apartheid. See MEC for KwaZulu-Natal Province, Housing v Msunduzi Municipality 2003 (4) BCLR 405 (N) at 412-413; Van Wyk 2012: 31.

78 According to its long title, the aim of the Black (Urban Areas) Act 21 of 1923 was to provide for "improved conditions of residence for natives in or near urban areas and the better administration of native affairs". In 1922, the Transvaal Local Government appointed the Stallard Commission to investigate the presence of black persons in urban areas. The Black (Urban Areas) Act 21 of 1923 was enacted based on the Commission's recommendations. See Transvaal Local Government 1922: par 267. 
authorising local authorities to demarcate, plan and develop separate locations. ${ }^{79}$ As alternative settlement options, the Act provided for the lease of municipal plots to black tenants ${ }^{80}$ and endorsed hostel accommodation for single black men working in urban areas. ${ }^{81}$ A prominent rationale underlying the accommodation of black persons in pre-apartheid urban areas was the need for steady access to affordable labour to advance the economy. Urban residential segregation thus enabled local authorities to implement influx control measures and to administer stricter pass laws. ${ }^{82}$

Although the housing options provided for by the Black (Urban Areas) Act 21 of 1923 enabled access to employment opportunities, they also enhanced the government's control over the spatial settlement patterns of black residents. ${ }^{83} \mathrm{In}$ 1925, for instance, the Johannesburg Municipality used the provisions of the Act to evict black tenants from a portion of the Malay Location. Despite provisions in the Black (Urban Areas) Act 21 of 1923 requiring displaced persons to be rehoused, the municipality did not have the financial resources to provide evictees with access to alternative accommodation. ${ }^{84}$ Evictions instituted in terms of the Act therefore frequently aggravated the spatial exclusion, housing deprivation and socio-economic marginalisation of black urban inhabitants.

The Regulations for the Administration and Control of Townships in Black Areas ${ }^{85}$ established limited conditions for black persons to lawfully purchase, rent or occupy land in the scheduled areas beyond pre-apartheid towns. ${ }^{86}$ The townships governed by the regulations differed from the formal residential locations established in or near urban areas, ${ }^{87}$ as they were consigned to the reserves and subject to the provisions of the Development Trust and Land Act 18 of 1936. However, the proximity of these townships to urban areas was significant, as they represented sources of labour for the urban economy. ${ }^{88}$ Significantly, black communities

79 Section 1(1)(a) of the Black (Urban Areas) Act 21 of 1923 provided local authorities with the power to "define, set apart and lay out one or more areas of land for the occupation, residence and other reasonable requirements of natives", which were called "locations". See, further, Van Wyk 2012: 48.

80 Section 1(1)(b) of the Black (Urban Areas) Act 21 of 1923.

81 Idem $\mathrm{s} 1(1)(\mathrm{c})$.

82 Maylam 1995: 29.

83 Harrison, Todes \& Watson 2008: 24.

84 Parnell 1991: 284.

85 Promulgated in terms of Proc R293 GG 373 of 16 Nov 1962 and adopted in terms of ss 6(2) and 25(1) of the Black Administration Act 38 of 1927 and s 21(1) of the Development Trust and Land Act 18 of 1936.

86 During the pre-apartheid period, black land tenure was traditionally divided into rural and urban categories. Van Wyk 2012: 45 explains that this distinction was largely arbitrary and technical. In essence, the term "rural" applied to land governed by the Black Land Act 27 of 1913 and the Development Trust and Land Act 18 of 1936. However, the term "urban" also applied in areas that, in the ordinary sense of the word, would have been categorised as rural.

87 The formal residential locations established for black persons in or near urban areas were governed by the provisions of the Black (Urban Areas) Act 21 of 1923 and the Black (Urban Areas) Consolidation Act 25 of 1945.

88 Wilson 2011: 6 . 
who resided in these townships did not enjoy tenure security in the form of ownership rights. ${ }^{89}$

Increased levels of urbanisation during the 1940s resulted in the proliferation of informal settlements. ${ }^{90}$ The Union government responded by enacting the Black (Urban Areas) Consolidation Act 25 of 1945, ${ }^{91}$ which enabled the implementation of formal influx-control policies. ${ }^{92}$ The provisions of the Act, in conjunction with the Regulations Concerning the Control and Supervision of an Urban Black Residential Area, ${ }^{93}$ were eventually used to establish formal townships for black inhabitants in urban areas under apartheid. ${ }^{94}$ In particular, section 2(1) of the Black (Urban Areas) Consolidation Act 25 of 1945 empowered local authorities to demarcate and plan spaces for black occupation. These areas included locations, vacant municipal land or buildings, and hostels. ${ }^{95}$ The settlement options provided for in the Act were subject to the approval of the Minister, who had to be satisfied with the planning and layout of the location, the suitability of the land, the condition of buildings, and the provision of essential services. ${ }^{96}$ Section 2(1) did not, however, require the Minister to consider the adequacy of the location or the quality of the housing spaces created in terms of the Black (Urban Areas) Consolidation Act 25 of 1945.

The next section examines the use of the Black Administration Act 38 of 1927 by the pre-apartheid government to control the spatial settlement patterns of black urban inhabitants through the practice of forced removals.

\section{Spatial displacement through forced removals}

Through the implementation of the Black Administration Act 38 of 1927, ${ }^{97}$ the preapartheid government accelerated the large-scale spatial displacement and control

89 Tongoane v Minister of Agriculture and Land Affairs 2010 (6) SA 214 (CC) par 16.

90 Harrison, Todes \& Watson 2008: 25.

91 According to the long title of the Black (Urban Areas) Consolidation Act 25 of 1945, the aim of the Act was to consolidate the laws that provided for "improved conditions of residence for natives in or near urban areas and the better administration of native affairs". This Act was later repealed by the Abolition of Racially Based Land Measures Act 108 of 1991.

92 In 1946, the state appointed the Native Laws Commission to investigate and recommend potential changes to the system of spatial and racial segregation. The Commission's recommendation in favour of permanently accommodating African settlement in urban areas was rejected. See Native Laws Commission 1946: passim.

93 The Regulations Concerning the Control and Supervision of an Urban Black Residential Area, GN 1036 GG 2096 of 14 Jun 1968 were issued in terms of s 38(3)(a) of the Black (Urban Areas) Consolidation Act 25 of 1945. These regulations had a long-term impact on the spatial settlement patterns of black persons, as they remained in force for many years in terms of s 66 of the Black Communities Development Act 4 of 1984. Section 72(1) of the Abolition of Racially Based Land Measures Act 108 of 1991 repealed the Black Communities Development Act 4 of 1984.

94 Van Wyk 2012: 48-49.

95 Section 2(1)(a)-(d) of the Black (Urban Areas) Consolidation Act 25 of 1945.

96 Idem s 2(2).

97 The Black Administration Act 38 of 1927 provided for the "better control and management of Black affairs". That Act was later repealed by the Repeal of the Black Administration Act and Amendment of Certain Laws Act 28 of 2005. 
of the majority black population. Section $5(1)(b)$, in particular, was a powerful mechanism for managing and reconfiguring urban space through the forced removal of black inhabitants..$^{98}$ In Western Cape Provincial Government: In re DVB Behuising (Pty) Ltd $v$ North West Provincial Government, ${ }^{99}$ the Constitutional Court encapsulated the role of the Black Administration Act 38 of 1927 in facilitating spatial displacement:

The Native Administrative Act 38 of 1927 appointed the Governor-General [later referred to as the State President] as "supreme chief" of all Africans. It gave him the power to govern Africans by proclamation. The powers given to him were virtually absolute. He could order the removal of an entire African community from one place to another. The Native Administration Act became the most powerful tool in the implementation of forced removals of Africans from the so-called "white areas" into the areas reserved for them. These removals resulted in untold suffering. This geographical plan of segregation was described as forming part of "a colossal social experiment and a long term policy". ${ }^{100}$

In practice, the Black Administration Act 38 of 1927 enabled the comprehensive spatial control and relocation of the black population ${ }^{101}$ and the administration of land tenure and land use in the scheduled reserves. ${ }^{102}$ It also established separate courts with the authority to apply indigenous laws. ${ }^{103}$ By appointing the Governor General as the "supreme chief" of all black people, ${ }^{104}$ the Act granted him extensive legislative, executive and judicial powers, which included the authority to evict and remove groups and individuals from any place. ${ }^{105}$ The provisions of the Black Administration Act 38 of 1927 thus enabled the pre-apartheid government to both control the presence of black persons in urban areas and to achieve the spatial reconfiguration of towns through the forced removal of thousands of black families and individuals to the scheduled reserves. ${ }^{106}$ These processes of spatial displacement and socio-economic marginalisation resulted in immense suffering and dispossession. ${ }^{107}$ The land dispossessions and evictions initiated under the Black

98 Section 5(1)(b) of the Black Administration Act 38 of 1927 stated that the "Governor-General may whenever he deems it expedient in the general public interest, order the removal of any tribe or portion therefore or any Native from any place to any other place within the Union upon such conditions as he may determine". Section 1(1) of the Repeal of the Black Administration Act and Amendment of Certain Laws Act 28 of 2005 repealed s 5(1)(b) of the Black Administration Act 38 of 1927.

992001 (1) SA 500 (CC).

100 Idem par 41.

101 Sections 3-5 of the Black Administration Act 38 of 1927.

102 Idem ss 6-8. See, further, Western Cape Provincial Government: In Re DVB Behuising (Pty) Ltd $v$ North West Provincial Government 2001 (1) SA 500 (CC) par 41; Van Wyk 2012: 43-44.

103 Section 11 of the Black Administration Act 38 of 1927. See, further, Tongoane v Minister of Agriculture and Land Affairs 2010 (6) SA 214 (CC) par 23.

104 Section 1 of the Black Administration Act 38 of 1927.

105 Idem s 5(1)(b).

106 Marcus 1990: 18-20.

107 Western Cape Provincial Government: In re DVB Behuising (Pty) Ltd v North West Provincial Government 2001 (1) SA 500 (CC) par 41. See, further, O'Regan 1989: 361-394; Van der Walt 2009: $137-138$. 
Administration Act 38 of 1927 also officially excluded black persons from urban areas for several years. ${ }^{108}$ The Act has accordingly been described as a "cornerstone of racial oppression, division and conflict" in South Africa. ${ }^{109}$

During the period preceding apartheid, the separate system of land-use management that applied to spaces occupied by black communities was subordinate to the planning schemes implemented in towns inhabited by white persons. The Black (Urban Areas) Act 21 of 1923 and the Black Administration Act 38 of 1927 reinforced these dual planning approaches and implemented spatial segregation in urban areas by facilitating the development of peripheral locations. Ultimately, confining black residents to separate settlements enabled local authorities to administer pass laws and influx control policies, while enhancing their political and socio-economic exclusion.

Between 1910 and 1948, the implementation of other forms of town planning furthered the spatial segregation, displacement and control of black residents. The next section examines some of the most prominent spatial consequences of the implementation of public health and safety legislation in urban areas during this period.

\section{Impact of health and safety legislation in urban areas}

The outbreak of bubonic plague in South Africa in 1901 sparked a powerful social metaphor that associated the presence of black persons in urban areas with poverty, disease and crime. Between 1910 and 1948, heightening paranoia increasingly equated the spread of infectious diseases with a growing number of multiracial inner city slums and urban black townships. ${ }^{110}$ Promoting the public health and safety interests of the white minority population accordingly became a driving force behind the government's broader imperative of advancing the spatial segregation and control of black urban dwellers. ${ }^{111}$ In 1918, for instance, the influenza epidemic focused the attention of health officials on the appalling living conditions in settlements, such as Ndabeni in Cape Town. ${ }^{12}$ The white residents responded by demanding that Ndabeni be demolished and its residents relocated to a more distant area. ${ }^{113}$ In Johannesburg, the 1918 epidemic also highlighted the unhealthy living conditions in that city's Malay Location. In order to manage overcrowding and the spread of disease in the area, the Johannesburg municipality established the Western Areas Native Township,

108 Tongoane v Minister of Agriculture and Land Affairs 2010 (6) SA 214 (CC) par 25.

109 Bhe v Magistrate Khayelitsha; Shibi v Sithole; South African Human Rights Commission v President of the Republic of South Africa 2005 (1) SA 580 (CC) par 61.

110 Parnell 1993: 483.

111 Maylam 1995: 24-25.

112 The Ndabeni settlement was established in 1901 to accommodate black persons who were forcibly expelled from Cape Town as a result of the bubonic plague. 113 Maylam 1995: 25. 
where limited housing was made available to black residents. The construction of the township contributed to the gradual spatial segregation of black inhabitants in Johannesburg. ${ }^{114}$

The evolving causal connection between these ostensible public health concerns and the imperative of spatial separation also informed the reports of government commissions. ${ }^{115}$ As a result, municipal health officials increasingly focused on the health concerns associated with the spaces where black urban inhabitants resided. ${ }^{116}$ In turn, the notion that spatial segregation would solve problems associated with unhealthy living conditions, overcrowding and disease among black communities in urban areas increased support for racial and spatial segregation. ${ }^{17}$

The Public Health Act 36 of 1919 was enacted to regulate overcrowding, as well as the location and density of housing settlements in urban areas. ${ }^{118}$ The implementation of the Act illustrates how the use of state planning practices in South Africa contributed to spatial, racial and social segregation. ${ }^{119}$ This is due to the fact that the Public Health Act 36 of 1919 facilitated the spatial displacement of black persons by providing for their removal from urban centres to peripheral sites under the guise of public health care. Once overcrowding was identified as a factor that exacerbated the spread of infectious diseases, municipalities began constructing segregated housing for black residents in remote parts of urban areas. In practice, however, these measures largely failed to address difficulties associated with providing safe and affordable housing for black urban inhabitants, as well as the broader impact of disease on affected communities. ${ }^{120}$

The provisions of the Public Health Act 36 of 1919 were also used in conjunction with, for example, the Housing Act 35 of 1920 to advance segregation, racialised urban planning and the eviction and removal of black inhabitants from urban areas. These legislative mechanisms proved invaluable in achieving segregated residential development in urban areas, as many of the regulations applicable to black urban settlements were incomplete, ineffective or ignored. ${ }^{121}$ The intersection between planning, public health administration and housing thus represented a key area where local authorities could regulate the living spaces and participation of black persons in urban life, while managing spatial development along racial lines.

114 Parnell 1991: 274, 282.

115 For instance, the 1914 Tuberculosis Commission identified and condemned black locations and urban slums as a health menace. See Union Government 1914: passim. See, further, Maylam 1995: 25.

116 Swanson 1977: 390; Parnell 1993: 487.

117 Parnell 1993: 483; Maylam 1995: 24-25; Harrison, Todes \& Watson 2008: 24.

118 Harrison, Todes \& Watson 2008: 24.

119 Parnell 1993: 472.

120 Idem at 483.

121 Parnell 1991: 273-274.` 
In addition, increased social and racial differentiation in urban areas during the early twentieth century resulted in planning approaches that encouraged the eradication of urban slums. ${ }^{122}$ English law inspired the provisions of the Slums Act 53 of 1934, ${ }^{123}$ as well as the development of local planning approaches to slum clearance and relocation. ${ }^{124}$ Although planning practices in England required local authorities to rebuild housing on the site of slum clearance schemes, ${ }^{125}$ South African municipalities frequently relocated black inhabitants to the urban periphery, where land and construction costs were lower. ${ }^{126}$ In Cape Town, for instance, the provisions of the Slums Act 53 of 1934 were used to remove multiracial inner-city slums and to develop housing schemes for so-called coloured persons on the Cape Flats. ${ }^{127}$ The Act also contained criteria and procedures for identifying, repairing, evacuating or demolishing housing spaces demarcated as slums. ${ }^{128}$ In conjunction with other legislation applicable to planning, health, and housing in urban areas, the provisions of the Slums Act 53 of 1934 were thus instrumental in effecting the large-scale eviction and peripheral relocation of black persons during the pre-apartheid period.

Pre-apartheid statutory measures thus facilitated the control and assignment of black inhabitants to racially segregated reserves. ${ }^{129}$ This process began with the creation of legislative assemblies, which turned into self-governing territories and ultimately into independent states, and was conducted in accordance with a broader plan to exclude black persons from spaces designated for the exclusive use and benefit of white persons. ${ }^{130}$ The final section of this contribution examines the use of legal frameworks to advance the colonial template and pre-apartheid foundations of spatial control, segregated urban development and housing deprivation during the apartheid period.

122 Parnell 1993: 478.

123 The long title of the Slums Act 53 of 1934 stated that it aimed to make "better provision for the elimination of slums within the areas of jurisdiction" of certain local authorities. Section 1 of that Act defined a "slum" as "any premises or any part of any premises which has been declared a slums under the provisions" of s 4 of the Act.

124 Parnell 1993: 481.

125 Dyos 1967: 5-40.

126 Parnell 1993: 481.

127 Maylam 1995: 27; Harrison, Todes \& Watson 2008: 24.

128 Sections 4-16 of the Slums Act 53 of 1934. Section 4(1) described a slum as a place where a medical officer indicated that a "nuisance" existed, which could be effectively remedied by applying the provisions of the Act.

129 Western Cape Provincial Government: In re DVB Behuising (Pty) Ltd v North West Provincial Government 2001 (1) SA 500 (CC) par 42.

130 Ex Parte Moseneke 1979 (4) SA 884 (T) at 889-890. 


\section{$5 \quad$ Consolidating spatial segregation during apartheid (1948-1990)}

\section{Entrenching spatial control and segregated urban development through law}

The election of the National Party in 1948 heightened the spatially unjust and racially discriminatory legislative and policy approaches of the colonial and pre- apartheid governments. Between 1948 and 1990, the apartheid state developed extensive legal mechanisms to implement racially based spatial segregation in urban areas. ${ }^{131}$ Most notably, these included the Population Registration Act 30 of 1950, the Group Areas Act 41 of 1950, the Black Education Act 47 of 1953, the Reservation of Separate Amenities Act 49 of 1953, the Group Areas Act 36 of 1966, the Black Local Authorities Act 102 of 1982, the Community Development Act 3 of 1966 and the Black Communities Development Act 4 of $1984 .{ }^{132}$ These statutes all contributed, in one way or another, to constructing the legacy of spatial injustice into South Africa's contemporary towns and cities by either demarcating or controlling black urban settlement. In essence, the state utilised this legal framework to regulate the use and development of land designated for black occupiers and to consolidate apartheidbased principles applicable to land, planning and urban settlement. ${ }^{133}$ In the area of land-use management, for instance, legislative and policy measures were key to eroding the remaining land rights (such as labour tenancy) that black persons had in sectors reserved for white persons. ${ }^{134}$

At national level, the apartheid legislative framework facilitated the creation of ethnically defined homelands and enabled the physical displacement of thousands of black persons, who were prohibited from living in areas other than the rural reserves. ${ }^{135}$ The spatial reconfiguration of South Africa's majority black population resulted in concentrated pockets of severe inequality, poverty and deprivation in the homelands and independent states. ${ }^{136}$ These spatial contradictions were magnified when the rapid economic development of the 1960s and 1970s dwindled. ${ }^{137}$ This

131 Parnell \& Mabin 1995: 41.

132 For an account of the myriad political, legal, social and cultural institutions that further entrenched racial inequality in South Africa during apartheid, see Van Reenen 1962: 323-328; Terreblanche 2002: 334-339.

133 Ross 2008: 126; Van Wyk 2012: 25. See Abrams v Allie NO 2004 (9) BCLR 914 (SCA) for examples of practices in terms of which these statutes established a framework of race classification.

134 For a description of the legal and institutional mechanisms that effected the dispossession of black people during apartheid, see the judgement of Moseneke DCJ in Department of Land Affairs $v$ Goedgelegen Tropical Fruits (Pty) Ltd 2007 (6) SA 199 (CC).

135 Budlender 1990: 74.

136 See, generally, Noble \& Wright 2012: 187-201.

137 Harrison, Todes \& Watson 2008: 33. 
is due to the fact that, for example, the movement of black labourers further away from the core of the urban economy contributed to severe transportation costs that required government subsidisation. ${ }^{138}$ Concurrently, the apartheid state prioritised economic development through a combination of discriminatory labour, market and educational policies. Jeremy Seekings and Nicoli Nattrass accordingly observe that no other "capitalist state (in either the North or the South)" structured income inequalities as methodically and severely as South Africa during apartheid. ${ }^{139}$

Due to their intersectional nature, racial discrimination deepened class divisions between 1948 and 1990. ${ }^{140}$ Accordingly, racial discrimination represented another dimension that advanced the spatial and social contradictions produced under apartheid, which remain largely unresolved in contemporary South Africa. The material consequences, severe poverty, and structural inequality produced under apartheid remained largely unresolved after the deracialisation of legal and policy frameworks in the late- and post-apartheid periods. ${ }^{141}$ Terreblanche aptly summarises this problem by explaining that although South Africa introduced a politicaleconomic system of democratic capitalism, it still represented "a system of democratic capitalism, legitimised by the ideology of liberal capitalism". ${ }^{142}$ In practice, state and market influences therefore retained their dominance over the development of urban space and settlement patterns.

The ensuing section examines the impact of key components of the extensive legislative framework that consolidated spatial control and facilitated the restructuring of apartheid urban areas.

\section{Restructuring the spatial form of apartheid urban areas}

Under apartheid, a variety of statutes applicable to land and planning demarcated and controlled urban black settlement and entrenched the insecure tenure status and poor location of housing of South Africa's black urban population. The Group Areas Act 41 of 1950, the Prevention of Illegal Squatting Act 52 of 1951, and the Physical Planning Act 88 of 1967 were all particularly instrumental in facilitating the restructuring of apartheid urban areas. The Group Areas Act 41 of 1950, which was modelled on the provisions of the Black (Urban Areas) Act 21 of 1923 and the Black (Urban Areas) Consolidation Act 25 of 1945, ${ }^{143}$ was a powerful mechanism

138 Maylam 1990: 60.

139 Seekings \& Nattrass 2005: 2.

140 Idem at 4.

141 Liebenberg 2010: 3 .

142 Terreblanche 2002: 18 (emphasis in original).

143 Mabin 1992a: 406 argues that a number of existing segregatory measures converged in the Group Areas Act 41 of 1950. The implementation of the Act depended on existing municipal planning structures that were put in place by legislation, such as the Housing Act 35 of 1920, the Black (Urban Areas) Act 21 of 1923 and the Black (Urban Areas) Consolidation Act 25 of 1945. 
for facilitating the spatial restructuring of apartheid urban areas. ${ }^{144}$ The Act enabled spatially segregated urban development through establishing land-use zones according to different racial groups, ${ }^{145}$ while controlling the tenure status, use and occupation of land within towns and cities. In practice, the Group Areas Act 41 of 1950 prohibited the multiracial use or occupation of urban land. ${ }^{146}$ The Act thus divided urban areas into segregated zones where only members of a particular race could reside and work. ${ }^{147}$ In doing so, it clearly designated urban spaces for the exclusive ownership and occupation of a particular group. ${ }^{148}$ Additionally, that Act made it possible to institute criminal proceedings against a person from one race who either owned or occupied land in an area designated for the exclusive use of another racial group. ${ }^{149}$

The implementation of the Group Areas Act 41 of 1950 had significant consequences for land-use management, municipal planning and settlement development in urban areas. It undermined, for instance, municipal autonomy by centralising or shifting state control over racial segregation to the national sphere..$^{150}$ This process paved the way for long-term racialised approaches to land-use planning, hampered the exercise of property rights, and facilitated the development of state housing for poorer segments of the urban population. ${ }^{151}$ Moreover, that Act extended compulsory spatial segregation to the so-called coloured population. ${ }^{152}$ Significantly, its application resulted in the large-scale eviction and spatial displacement of thousands of black urban dwellers from well-located multiracial settlements in inner cities during the 1950s. ${ }^{153}$ These forced removals coincided with the development of massive peripheral townships, ${ }^{154}$ which have become a defining feature of South African urban areas due to their location and standardised layouts. The location of these separate residential areas further enhanced the state's control over black urban inhabitants, ${ }^{155}$ as they were surrounded by industrial buffer zones or vacantland. ${ }^{156}$

144 Dodson 1990: 137-161.

145 Section 12(1) of the Group Areas Act 41 of 1950 characterised different racial groups as "white", "black" and "coloured".

146 Dodson 1990: 145-147.

147 Thompson 1990: 194.

148 Christopher 1994: 105. See, further, Christopher 1992: 561-582.

149 Dyzenhaus 1991: 71.

150 Mabin 1992a: 407.

151 Ibid.

152 Ibid. See, further, Trotter 2009: 49-78.

153 Van der Walt 2009: 60.

154 Harrison, Todes \& Watson 2008: 26.

155 Idem at 27.

156 By the late 1960s, the emphasis on development in South Africa's major urban areas shifted to the construction of towns in the African rural reserves. See, further, Harrison, Todes \& Watson 2008: 27. 
The Prevention of Illegal Squatting Act 52 of 1951 was equally instrumental in effecting the spatial restructuring of apartheid towns and cities. ${ }^{157}$ The Act regulated the unlawful occupation and use of public and private land ${ }^{158}$ by authorising the Minister of Native Affairs to compel black urban dwellers living on public or private land to relocate to established resettlement camps and by imposing severe criminal sanctions. ${ }^{159}$ It also had a particularly detrimental impact on local authorities' approaches to informal settlement development. ${ }^{160}$

The Prevention of Illegal Squatting Act 52 of 1951 was amended in 1977. ${ }^{161}$ In 1986, a further amendment in terms of the Abolition of Influx Control Act 68 of 1986 provided for an alternative type of informal settlement area for black urbanites, which was commonly referred to as a "designated area". ${ }^{162}$ In practice, the legislative amendment introduced a form of controlled squatting in urban areas that was directly linked to influx-control policies. ${ }^{163}$ The amendment also enabled portions of stateowned land to be allocated for the housing needs of poor segments of the urban population who were incapable of accessing alternative accommodation. ${ }^{164}$ Unlike the transit camps developed during apartheid for accommodating evictees, ${ }^{165}$ these designated areas provided more permanent access to housing options. In the case of both transit camps and designated areas, the ordinary township planning rules and provisions of the Group Areas Act 36 of 1966 and the Slums Act 76 of 1979 did not apply. ${ }^{166}$ Additionally, the designated areas provided a more flexible tool for accommodating the influx of black persons into urban areas and a potential alternative to instituting forced evictions and relocations. ${ }^{167}$

157 O’Regan 1989: 362.

158 O'Regan 1990: 163.

159 Sections 1 and 2 of the Prevention of Illegal Squatting Act 52 of 1951.

160 Section 3 authorised the eviction of illegal occupants and the demolition of any structures erected on unlawfully occupied public or private land. Section 4 prohibited municipalities from exercising authority over informal settlements, while ss 5 and 8 sanctioned the removal of unlawful occupiers.

161 The Riekert Commission of Inquiry into Manpower Utilisation was established in terms of GN 1673 GG 5720 of 26 Aug 1977. The Commission recommended that African labourers be afforded access to urban areas on condition that adequate accommodation was made available for them. See, further, O'Regan 1989: 373

162 Section 6A(1) of the Abolition of Influx Control Act 68 of 1986 amended the Prevention of Illegal Squatting Act 52 of 1951

163 O'Regan 1989: 367.

164 Idem at 393.

165 Section 6(5) of the Prevention of Illegal Squatting Act 52 of 1951 provided a local authority with the power to make regulations for the establishment of transit camps. Local authorities could use land they owned for purposes of establishing transit camps.

166 Different versions of the Group Areas Act 41 of 1950 were enacted, including the Group Areas Act 77 of 1957 and the Group Areas Act 1936 of 1966. These statutes consolidated the compulsory principle of developing segregated urban settlements. See, further, Pienaar 2014: 106-107.

167 O’Regan 1989: 393. 
However, neither the Prevention of Illegal Squatting Act 52 of 1951 nor the Abolition of Influx Control Act 68 of 1986 addressed the need for integrated housing settlement opportunities for black inhabitants who could not access formal housing in urban areas. Instead, the 1988 amendment to the Prevention of Illegal Squatting Act 52 of 1951 introduced further measures to control "squatters" or persons residing unlawfully in urban areas. In particular, the Prevention of Illegal Squatting Amendment Act 104 of 1988 empowered local authorities and private landowners to demolish housing structures and forcibly remove black dwellers. ${ }^{168}$

The effective implementation of the Prevention of Illegal Squatting Act 52 of 1951 in urban areas was guaranteed by the enactment of a comprehensive framework of equally discriminatory legislation. ${ }^{169}$ These included the Black Laws Amendment Act 54 of 1952, ${ }^{170}$ the Blacks (Abolition of Passes and Co-ordination of Documents) Act 67 of 1952 and the Black Service Levy Act 64 of 1952. Moreover, the Prevention of Illegal Squatting Act 52 of 1951 was implemented in conjunction with the Slums Act 76 of 1979, the Trespass Act 6 of 1959, the Physical Planning Act 88 of 1967 and the Health Act 63 of 1977 to control issues associated with health, safety and housing in the areas occupied by black urban inhabitants. ${ }^{171}$

The Prevention of Illegal Squatting Act 52 of 1951 thus regulated the unlawful occupation and use of public and private land by authorising the removal of black urban dwellers to established resettlement sites or transit camps. Moreover, it enabled the allocation of portions of state-owned land for accommodating the housing needs of the urban and urbanising poor. After 1986, the Act facilitated the creation of designated areas. This alternative type of informal settlement area provided access to more permanent housing alternatives for black migrants and represented an alternative approach to managing the growing urban black population. However, the need for spatially integrated urban settlement options remained unaddressed.

Within this complex legislative framework, the Physical Planning Act 88 of 1967 was vital in guiding the apartheid spatial segregation of South African urban areas. Throughout the 1950s and 1960s, the state attempted to centralise control over local planning processes associated with the increased urbanisation of black persons. ${ }^{172}$ The Physical Planning Act 88 of 1967 authorised the state to control and prescribe local planning practices through the preparation of master guide plans for local areas approved in terms of section $6 \mathrm{~A}(10)$ of the Act. ${ }^{173}$ In other words, the Act

168 Idem at 362.

169 Idem at 369.

170 The Black Laws Amendment Act 54 of 1952 amended the Black (Urban Areas) Consolidation Act 25 of 1945.

171 The Prevention of Illegal Squatting Act 52 of 1951 was repealed by s 11(1), read with Schedule 1, of the Prevention of Illegal Eviction from and Unlawful Occupation of Land Act 19 of 1998.

172 Harrison, Todes \& Watson 2008: 29.

173 Mabin 1992a: 407. 
contributed to spatially segregated development by enabling the apartheid state to centralise the control of municipal planning processes and the management of black urban townships.

In 1972, the administration and management of black urban townships shifted from municipalities to centralised state-controlled administration boards. Planning practices implemented in terms of the Physical Planning Act 88 of 1967 comprised ambitious spatial reconfiguration programmes aimed at both the local and regional levels. In practice, these planning approaches were largely ineffectual and contributed to the proliferation of informal settlements on the urban edge. This is due to the fact that many black migrants resorted to accessing urban areas and resources by adapting their basic survival strategies through the occupation of vacant plots of land or open spaces in or near towns and cities. ${ }^{174}$ For many black urban inhabitants, vacant plots of land or open spaces and buildings were thus the only spaces where they could secure a fragile foothold in towns and cities.

During late-apartheid, the townships represented powerful sites where black urban inhabitants challenged the political status quo. ${ }^{175}$ Accordingly, the apartheid state became increasingly concerned with how to address the growing presence of black inhabitants in urban areas. The final section of this article examines the abolition of influx-control measures and the state's attempt at facilitating "orderly urbanisation" in South African towns and cities towards the end of apartheid.

\section{3 "Orderly urbanisation" and the abolition of urban influx controls}

During the 1980s, the apartheid state investigated alternative strategies to address the effects of rapid urbanisation and the migration of black people to towns and cities. In 1985, a report by the Constitutional Affairs Committee called for the abolition of influx-control measures in urban areas. In particular, the report proposed that racially defined controls over black settlements be replaced with neutral measures in the form of planning and health and safety legislation. ${ }^{176}$ These recommendations were incorporated into the White Paper on an Urbanisation Strategy for the Republic of South Africa (hereafter White Paper on Urbanisation). ${ }^{177}$ The notion of "orderly urbanisation" was central to the White Paper on Urbanisation and entailed accommodating the presence of black inhabitants in urban areas through the establishment of a middle class with secure tenure rights. This new policy approach introduced measures to ensure that urbanisation happened in a planned and controlled manner in parts of towns and cities designated for black settlement - most often at

174 Royston 1998: 146; Soni 1992: 43.

175 Maylam 1990: 83.

176 Hindson 1987: 78

177 Constitutional Affairs Committee 1985: passim. 
the urban periphery. ${ }^{178}$ Stated differently, the White Paper on Urbanisation set out a strategy to contain the unlawful occupation of land and to manage the development of informal settlements. In turn, this strategy authorised the state to plan and demarcate spaces where the growing urban black population could be accommodated. ${ }^{179}$ The policy approach advanced by the White Paper on Urbanisation therefore enhanced, rather than challenged, the spatial imbalances in urban residential settlement.

The policy of orderly urbanisation was enforced through various legal measures and other more subtle forms of restrictions applicable to black urban inhabitants. ${ }^{180}$ The strategy also allowed for controlled squatting on demarcated land through the upgrading of invaded land or the orderly development of uninhabited land - primarily through the involvement of the private sector. ${ }^{181}$ In practice, however, the strategy caused ambiguity regarding development approaches to informal settlements, which ranged from demolition to upgrading. ${ }^{182}$ During this period, the state's predominant development approach was to afford selected informal settlements the status of transit camps until a site-and-service project was ready for implementation and the affected community could be relocated. ${ }^{183}$ Localised solutions that prioritised the upgrading of an existing occupied site were only considered in cases where affected black communities vehemently contested their relocation. ${ }^{184}$ Additionally, local authorities retained the power to relocate poor urban inhabitants, whose homes had been subjected to eviction or demolition on one informal site, to an approved albeit equally informal location. ${ }^{185}$

The strategy of orderly urbanisation was unsuccessful insofar as the apartheid state's extensive legal framework could not prevent land invasions or the continued growth of informal settlements on the peripheries of urban areas. ${ }^{186}$ As black migrants continued to defy influx-control measures in favour of settling in rapidly growing informal settlements, the government enacted the Abolition of Influx Control Act 68 of $1986 .{ }^{187}$ Informal settlements thus became vital housing spaces for the urban poor that existed outside of legal and planning frameworks. Evictions and forced relocations were instrumental in advancing spatial and racial segregation through the planning of land use. ${ }^{188}$ Forced removals and restrictions on migration

178 Harrison, Todes \& Watson 2008: 33.

179 Sutcliffe, Todes \& Walker 1990: 91.

180 Budlender 1990: 74; Huchzermeyer 2004: 1.

181 Huchzermeyer 2004: 1.

182 Harrison 1992: 18.

183 Huchzermeyer 2004: 1-2.

184 Ibid.

185 O’Regan 1989: 393.

186 Hindson 1987: 98; Harrison, Todes \& Watson 2008: 33.

187 For a discussion of the Abolition of Influx Control Act 68 of 1986, see Schoombee \& Davis 1986: 208-218.

188 Bundy 1990: 6; Van der Walt 2009: 60-62. 
also led to dense settlements on the periphery of urban areas, where many of South Africa's urban poor still reside today. ${ }^{189}$ This has serious consequences for advancing development in areas such as infrastructure, transport, housing, health and labour in contemporary towns and cities.

During the final years of apartheid, black residential townships represented powerful spaces of political contestation. The township uprisings of 1984, for instance, contributed to the end of attempts to establish viable black local authorities in urban areas. Cumulatively, the political contestation in the townships, international economic sanctions and a flailing economy contributed to the eventual demise of apartheid. ${ }^{190}$

\section{Conclusion}

Spatial injustice and urban residential segregation represent significant dimensions in the historical development of the segregated settlement patterns of South Africa's urban poor, which have strong links to colonialism and apartheid. This contribution contextualises the myriad political, economic, legal and social factors underlying the legacy of spatial injustice and socio-economic exclusion that characterise the housing crisis afflicting South Africa's contemporary urban areas. The housing needs of South Africa's urban poor are inextricably linked to this complex system of factors. ${ }^{191}$ Acknowledging this interrelationship is essential before seeking possible solutions or alternative approaches to meeting the housing needs of vulnerable and marginalised urban inhabitants. ${ }^{192}$

The historical exposition in this contribution examines the colonial origin and apartheid foundation of spatially segregated urban settlement in South Africa. Part one provides an overview of the spatial organisation and settlement patterns of indigenous populations prior to the colonial occupation of southern Africa and considers how municipal and public health administration, planning, land-use management and industrialisation contributed to segregated urban development in the earliest major colonial settlements. Part two spans the pre-apartheid period and investigates the use of legal mechanisms to legitimate and enable the systematic dispossession, spatial segregation, political control and socio-economic marginalisation of the majority black population. In particular, that section explores the role of the state in enabling spatial control, segregation, displacement and dispossession through land-use management, planning, public health and safety administration, evictions and forced removals. Cumulatively, these measures established the foundation for spatially segregated urban development during apartheid. The final part of this contribution

189 Smit 2006: 111-115.

190 Harrison, Todes \& Watson 2008: 33.

191 Pienaar 2002a: 16.

192 Van Wyk 2012: 592. 
examines the use of legal frameworks by the apartheid state to consolidate spatial control and segregated settlement development in towns and cities. In doing so, it provides insight into the extensive legislative framework, as well as the political, economic and social contexts that contributed to the spatial restructuring of apartheid urban areas and entrenched the spatially unjust settlement patterns that characterise contemporary urban South Africa.

This contribution also draws attention to the dominant role of the state in constructing and sustaining spatially and racially segregated urban settlement patterns at the national, regional and local levels through the implementation of various administrative, political and legal mechanisms. In doing so, it illustrates the significant function of the state as the primary developer of space at the intersection of land, planning and housing, which represents a further prominent dimension and source of spatial injustice and segregated urban development in South Africa. ${ }^{193}$ Moreover, it discloses the role of law in legitimating this function through regulations, prohibitions and sanctions that enabled the state to establish and sustain spatial injustice and inequality in towns and cities. ${ }^{194}$

South Africa's history of land, planning, housing and the development of informal settlements is deeply rooted in a legacy of spatial injustice that was entrenched by a plethora of discriminatory legislation. ${ }^{195}$ As a result, the legal system used to develop urban space in the areas of land-use management, planning and housing has historically operated on a spatially and racially exclusive basis. ${ }^{196}$ Accordingly, black South Africans inherited a mixed legacy of disparities in access to urban opportunities and the housing spaces they were consigned to during centuries of oppression. Developing comprehensive legal and policy responses that address the complex nature of spatial injustice and exclusion in urban areas thus represents an important dimension of future initiatives aimed at enabling South Africa's urban poor to access integrated and sustainable settlement and livelihood opportunities in towns and cities.

\section{Bibliography}

Badenhorst, PJ, J Pienaar \& H Mostert (2006) Silberberg and Schoeman's the Law of Property 5 ed (Durban)

Baines, G (1990) "The origins of urban segregation: Local government and the residence of Africans in Port Elizabeth, c. 1835-1865" South African Historical J 22(1): 61-81

193 Strauss 2017: 80.

194 Butler 2009: 324; Strauss 2017: 80.

195 Pienaar 2002b: 337.

196 Pienaar 2002a: 1. 


\section{A HISTORICAL EXPOSITION OF SPATIAL INJUSTICE}

Bouch, R (1993) “Glen Grey before Cecil Rhodes: How a crisis of local colonial authority led to the Glen Grey Act of 1894" Canadian J of African Studies 27(1): 1-24

Budlender, G (1990) "Urban land issues in the 1980s: The view from Weiler's farm" in C Murray \& C O'Regan (eds) No Place to Rest: Forced Removals and the Law in South Africa (Cape Town): $66-85$

Bundy, C (1990) "Land, law and power: Forced removals in historical context" in C Murray \& C O'Regan (eds) No Place to Rest: Forced Removals and the Law in South Africa (Cape Town): 3-12

Bunting, B (1964) The Rise of the South African Reich (London)

Butler, C (2009) "Critical legal studies and the politics of space" Social and Legal Studies 18(3): 313-332

Christopher, A (1987) "Apartheid planning in South Africa: The case of Port Elizabeth" Geographical J 153(2): 195-204

Christopher, A (1990) "Apartheid and urban segregation levels in South Africa" Urban Studies 27(3): 421-440

Christopher, A (1991) "Port Elizabeth" in A Lemon (ed) Homes Apart: South Africa's Segregated Cities (Cape Town): 43-57

Christopher, A (1992) "Segregation levels in South African cities, 1911-1985" International J of African Historical Studies 25(3): 561-582

Christopher, A (1994) The Atlas of Apartheid (London)

Constitutional Affairs Committee (1985) White Paper: An Urbanisation Strategy for the Republic of South Africa (PC3-1985)

Davenport, T \& C Saunders (2000) South Africa: A Modern History 5 ed (London)

Dodson, A (1990) "The Group Areas Act: Changing patterns of enforcement" in C Murray \& C O'Regan (eds) No Place to Rest: Forced Removals and the Law in South Africa (Cape Town): 137-161

Dyos, H (1967) “The slums of Victorian London” Victorian Studies 11(1): 5-40

Dyzenhaus, D (1991) Hard Cases in Wicked Legal Systems: South African Law in the Perspective of Legal Philosophy (Oxford)

Eldredge, E (1992) "Sources of conflict in southern Africa, c 1800-30: The 'Mfecane' reconsidered" $J$ of African History 33(1): 1-35

Feinberg, H (1995) "Pre-apartheid African land ownership and the implications for the current restitution debate in South Africa" Historia 40(2): 48-63

Gugler, J (1996) "Urbanization in Africa south of the Sahara: New identifies in conflict" in J Gugler (ed) The Transformation of the Developing World (Oxford): 221-252

Hardoy, J \& D Satterthwaite (1989) Squatter Citizen: Life in the Urban Third World (London)

Harrison, P (1992) "The policies and politics of informal settlement in South Africa: A historical perspective" Africa Insight 22(1): 14-22

Harrison, P, A Todes \& V Watson (2008) Planning and Transformation: Learning from the Postapartheid Experience (London)

Hindson, D (1987) “Orderly urbanization and influx control: From territorial apartheid to regional spatial ordering in South Africa" in R Tomlinson \& M Addleson (eds) Regional 


\section{MARGOT STRAUSS}

Restructuring under Apartheid: Urban and Regional Policies in Contemporary South Africa (Johannesburg): 74-105

Huchzermeyer, M (2004) Unlawful Occupation: Informal Settlements and Urban Policy in South Africa and Brazil (Trenton)

Huffman, TN (1992) "Southern Africa to the south of the Zambezi" in M Elfasi \& I Hrbek (eds) General History of Africa III: Africa from the Seventh to the Eleventh Century (Paris): 664680

Kirk, JF (1991) "Race, class, liberalism, and segregation: The 1883 Native Strangers' Location Bill in Port Elizabeth, South Africa" International J of African Historical Studies 24(2): 293 321

Laburn-Peart, C (2002) "Precolonial towns of southern Africa: Integrating the teaching of planning history and urban morphology" J of Planning Education and Research 21(3): 267-273

Lewis, C (1985) “The modern concept of ownership of land” Acta Juridica: 241-266 Liebenberg,

S (2010) Socio-economic rights: Adjudication under a Transformative Constitution (Cape Town)

Loveland, I (1999) Due Process of Law? Racial Discrimination and the Right to Vote in South Africa 1855-1960 (Oxford)

Mabin, A (1986) "Labour, capital, class struggle and the origins of residential segregation in Kimberley" J of Historical Geography 12(1): 4-26

Mabin, A (1991) "Origins of segregatory urban planning in South Africa, c 1900-1940" Planning History 13(3): 8-16

Mabin, A (1992a) "Comprehensive segregation: The origins of the Group Areas Act and its planning apparatuses" J of Southern African Studies 18(2): 405-429

Mabin, A (1992b) "Dispossession, exploitation and struggle: An historical overview of South African urbanization" in DM Smith (ed) The Apartheid City and beyond: Urbanization and Social Change in South Africa (Johannesburg): 13-24

Mabin, A (1993) "Conflict, continuity and change: Locating "properly planned native townships in the forties and fifties"' South African Planning History v(i): 305-337

Mabin, A \& D Smith (1997) "Reconstructing South Africa's cities? The making of urban planning 1900-2000” Planning Perspectives 12(2): 193-223

Marcus, G (1990) "Section 5 of the Black Administration Act: The case of the Bakwena ba Mogopa" in C Murray \& C O'Regan (eds) No Place to Rest: Forced Removals and the Law in South Africa (Cape Town): 13-26

Maylam, P (1990) "The rise and decline of urban apartheid in South Africa" African Affairs 89(354): 57-84

Maylam, P (1995) "Explaining the apartheid city: 20 years of South African urban historiography" J of Southern African Studies 21(1): 19-38

Native Laws Commission (1946) Native Laws Commission Report on Africans in Urban Areas

National Planning Commission (2012) National Development Plan 2030: Our Future - Make it Work (Pretoria)

Nel, EL (1991) "Racial segregation in East London, 1836-1948” South African Geographical J 73(2): 60-68 


\section{A HISTORICAL EXPOSITION OF SPATIAL INJUSTICE}

Noble, M \& G Wright (2012) "Using indicators of multiple deprivation to demonstrate the spatial legacy of apartheid in South Africa" Social Indicators Research 112(1): 187-201

O'Regan, C (1989) "No more forced removals? An historical analysis of the Prevention of Illegal Squatting Act" SAJHR 5(3): 361-394

O’Regan, C (1990) “The Prevention of Illegal Squatting Act” in C Murray \& C O'Regan (eds) No Place to Rest: Forced Removals and the Law in South Africa (Cape Town): 162-179

Parnell, S (1991) "Sanitation, segregation and the Native (Urban Areas) Act: African exclusion from Johannesburg's Malay Location, 1897-1925” J of Historical Geography 17(3): 271-288

Parnell, S (1993) "Creating racial privilege: The origins of South African public health and town planning" J of Southern African Studies 19(3): 471-488

Parnell, S \& A Mabin (1995) "Rethinking urban South Africa" J of South African Studies 21(1): 39-61

Pienaar, JM (2002a) "Planning, informal settlement and housing in South Africa: The Development Facilitation Act in view of Latin American and African developments" CILSA 35(1): 1-25

Pienaar, JM (2002b) "The housing crisis in South Africa: Will the plethora of policies and legislation have a positive impact?” Southern African Public Law 17: 336-370

Pienaar, JM (2014) Land Reform (Cape Town)

Pirie, G (1991) "Kimberley" in A Lemon (ed) Homes Apart: South Africa's Segregated Cities (Cape Town): 120-128

Rakodi, C (1986) "Colonial urban policy and planning in Northern Rhodesia and its legacy" Third World Planning Review 8(3): 193-217

Robertson, M (1990) "Dividing the land: An introduction to apartheid land law" in C Murray \& C O'Regan (eds) No Place to Rest: Forced Removals and the Law in South Africa (Cape Town): 122-136

Ross, A (2008) A Concise History of South Africa 2 ed (Cape Town)

Royston, L (1998) "South Africa: The struggle for access to the city in the Witwatersrand region" in A Azuela, E Duhau \& E Ortiz (eds) Evictions and the Right to Housing: Experiences from Canada, Chile, the Dominican Republic, South Africa, and South Korea (Ottawa): 145-197

Schoombee, JT \& DM Davis (1986) "Abolishing influx control: Fundamental or cosmetic change?" SAJHR 2(2): 208-218

Seekings, J \& N Nattrass (2005) Class, Race and Inequality in South Africa (Michigan)

Smedley, A \& BD Smedley (2005) "Race as biology is fiction, racism as social problem is real: Anthropological and historical perspectives on the social construction of race" American Psychologist 60(1): 16-26

Smit, W (2006) "Understanding the complexities of informal settlements: Insights from Cape Town" in M Huchzermeyer \& A Karam (eds) Informal Settlements: A Perpetual Challenge? (Cape Town): 103-125

Soni, D (1992) “The apartheid state and black housing struggles" in DM Smith (ed) The Apartheid City and Beyond: Urbanization and Social Change in South Africa (London): 39-53

Strauss, M (2017) A Right to the City for South Africa's Urban Poor (LLD, University of Stellenbosch) 


\section{MARGOT STRAUSS}

Strauss, M \& S Liebenberg (2014) "Contested spaces: Housing rights and evictions law in postapartheid South Africa" Planning Theory 13(4): 428-448

Sutcliffe, M, A Todes \& N Walker (1990) "Managing the cities: An examination of state urbanization policies since 1986" in C Murray \& C O’Regan (eds) No Place to Rest: Forced Removals and the Law in South Africa (Cape Town): 86-106

Swanson, M (1973) “"The Durban system”: Roots of urban apartheid in colonial Natal” African Studies 35(3/4): 159-176

Swanson, M (1977) "The sanitation syndrome: Bubonic plague and urban native policy in the Cape Colony, 1900-1909” J of African History 18(3): 387-410

Terreblanche, S (2002) A History of Inequality in South Africa 1652-2002 (University of KwaZulu-Natal)

Thompson, L (1990) A History of South Africa (New Haven)

Transvaal Local Government (1922) Commission Report of the Transvaal Local Government Commission (TP1-1922)

Trotter, H (2009) "Trauma and memory: The impact of apartheid-era forced removals on coloured identity in Cape Town" in M Adhikari (ed) Burdened by Race: Coloured Identities in Southern Africa (Cape Town): 49-78

Union Government (1914) Report of the Tuberculosis Commission(34/14)

Van der Walt, A (2009) Property in the Margins (Oxford)

Van Reenen, TH (1962) Land, its Ownership and Occupation in South Africa: A Treatise on the Group Areas Act, No 77 of 1957 and the Group Areas Development Act, No 69 of 1955 (Cape Town)

Van Wyk, J (2012) Planning Law 2 ed (Cape Town)

Wilson, F (2011) "Historical roots of inequality in South Africa" Economic History of Developing Regions 26(1): 1-15

\section{Case law}

Abrams v Allie NO 2004 (9) BCLR 914 (SCA)

Alexkor Ltd v Richtersveld Community 2004 (5) SA 460 (CC)

Bhe v Magistrate Khayelitsha; Shibiv Sithole; South African Human Rights Commission v President of the Republic of South Africa 2005 (1) SA 580 (CC)

Department of Land Affairs v Goedgelegen Tropical Fruits (Pty) Ltd 2007 (6) SA 199 (CC)

Ex parte Moseneke 1979 (4) SA 884 (T)

MEC for KwaZulu-Natal Province, Housing v Msunduzi Municipality 2003 (4) BCLR 405 (N)

Tongoane v National Minister for Agriculture and Land Affairs 2010 (6) SA 214 (CC)

Tsewu v Registrar of Deeds 1905 TS 130

Western Cape Provincial Government: In re DVB Behuising (Pty) Ltd v North West Provincial Government 2001 (1) SA 500 (CC) 


\section{Legislation}

Abolition of Influx Control Act 68 of 1986

Abolition of Racially Based Land Measures Act 108 of 1991

Black Administration Act 38 of 1927

Black Communities Development Act 4 of 1984

Black Education Act 47 of 1953

Black Land Act 27 of 1913

Black Laws Amendment Act 54 of 1952

Black Local Authorities Act 102 of 1982

Black Service Contract Act 24 of 1932

Black Service Levy Act 64 of 1952

Black (Urban Areas) Act 21 of 1923

Black (Urban Areas) Consolidation Act 25 of 1945

Blacks (Abolition of Passes and Co-ordination of Documents) Act 67 of 1952

Community Development Act 3 of 1966

Constitution of the Republic of South Africa, 1996

Development Trust and Land Act 18 of 1936

Glen Grey Act of 1894 (Cape)

Grondwet van de Zuid-Afrikaansche Republiek, 1858

Grondwet van de Zuid-Afrikaansche Republiek, 1889

Grondwet van de Zuid-Afrikaansche Republiek, 1896

Group Areas Act 41 of 1950

Group Areas Act 77 of 1957

Group Areas Act 36 of 1966

Health Act 63 of 1977

Housing Act 35 of 1920

Native Administration Act 3 of 1879 (Cape)

Natives Land Act 27 of 1913

Native Locations Act 37 of 1897 (Natal)

Native Locations, Lands and Commonages Act 40 of 1879 (Cape)

Native Reserve Locations Act 40 of 1902 (Cape)

Native Reserve Locations Act 2 of 1904 (Natal)

Physical Planning Act 88 of 1967

Population Registration Act 30 of 1950 Precious and Base Metals Act 35 of 1908

Prevention of Illegal Eviction from and Unlawful Occupation of Land Act 19 of 1998

Prevention of Illegal Squatting Act 52 of 1951

Prevention of Illegal Squatting Amendment Act 104 of 1988 


\section{MARGOT STRAUSS}

Public Health Act 36 of 1919

Regulations concerning the Control and Supervision of an Urban Black Residential Area, GN 1036 Government Gazette 2096 of 14 June 1968

Regulations for the Administration and Control of Townships in Black Areas, Proclamation R293 Government Gazette 373 of 16 November 1962

Repeal of the Black Administration Act and Amendment of Certain Laws Act 28 of 2005

Reservation of Separate Amenities Act 49 of 1953

Restitution of Land Rights Act 22 of 1994

Slums Act 53 of 1934

Slums Act 76 of 1979

Trespass Act 6 of 1959

Union of South Africa Act of 1909 